\title{
Vaccination with a non-human random sequence amyloid oligomer mimic results in improved cognitive function and reduced plaque deposition and micro hemorrhage in Tg2576 mice
}

Suhail Rasool ${ }^{1,2}$, Ricardo Albay III', Hilda Martinez-Coria ${ }^{3}$, Leonid Breydo ${ }^{1}$, Jessica Wu', Saskia Milton ${ }^{1}$, Sunit Misra ${ }^{1}$, Andy Tran ${ }^{1}$, Anna Pensalfini', Frank Laferla ${ }^{3}$, Rakez Kayed ${ }^{4,5}$ and Charles G Glabe ${ }^{1 *}$

\begin{abstract}
Background: It is well established that vaccination of humans and transgenic animals against fibrillar A amyloid accumulation in plaques and preserves cognitive function in transgenic mouse models. However, autoimmune side effects have halted the development of vaccines based on full length human A . Further development of an effective vaccine depends on overcoming these side effects while maintaining an effective immune response.

Results: We have previously reported that the immune response to amyloid oligomers is largely directed against generic epitopes that are common to amyloid oligomers of many different proteins and independent of a specific amino acid sequence. Here we have examined whether we can exploit this generic immune response to develop a vaccine that targets amyloid oligomers using a non-human random sequence amyloid oligomer. In order to study the effect of vaccination against generic oligomer epitopes, a random sequence oligomer ( $3 \mathrm{~A}$ ) was selected as it forms oligomers that react with the oligomer specific A11 antibody. Oligomer mimics from 3A peptide, A 3 , islet amyloid polypeptide (IAPP), and A $\beta$ fibrils were used to vaccinate Tg2576 mice, which develop a progressive accumulation of plaques and cognitive impairment. Vaccination with the $3 \mathrm{~A}$ random sequence antigen was just as effective as vaccination with the other antigens in improving cognitive function and reducing total plaque load (A $\beta$ burden) in the Tg2576 mouse brains, but was associated with a much lower incidence of micro hemorrhage than $A \beta$ antigens.
\end{abstract}

Conclusion: These results shows that the amyloid $A \beta$ sequence is not necessary to produce a protective immune response that specifically targets generic amyloid oligomers. Using a non-human, random sequence antigen may facilitate the development of a vaccine that avoids autoimmune side effects.

\footnotetext{
* Correspondence: cglabe@uci.edu

'Department of Molecular Biology and Biochemistry, University of California, Irvine, CA 92697, USA

Full list of author information is available at the end of the article
} 


\section{Background}

Alzheimer's disease (AD) is associated with progressive cognitive decline, neuronal loss and the accumulation of senile plaques and neurofibrillary tangles in affected regions of the brain [1]. The original amyloid cascade hypothesis $[2,3]$ proposed that the accumulation of amyloid plaques was the principal factor in AD pathogenesis. However recent studies indicate that small soluble $A \beta$ aggregates or oligomers may represent the primary pathogenic entities [4-9]. One of the first tests of the therapeutic value of preventing the accumulation of $A \beta$ or facilitating its clearance came from studies by ELAN, who immunized transgenic mouse models of $A D$ with $A \beta 42$ fibrils (fA $\beta 42)$ [10]. Immunization with $f A \beta 42$ (AN1792) results in a nearly complete absence of $A \beta$ plaque deposits, both in mice that were vaccinated prior to the onset of amyloid deposition and in animals that were vaccinated after amyloid deposition was well underway. However, human clinical trials were halted due to a high incidence of meningioencephalitis that is presumably due to an auto inflammatory reaction to immunization with human $A \beta$. Overcoming the auto inflammatory side effects while maintaining an effective immune response is a hurdle that must be overcome for the development of a human vaccine for AD [11].

We have previously shown that vaccination of transgenic mouse models of amyloid deposition with an $A \beta$ oligomer mimic antigen is just as effective in reducing amyloid deposition and preventing cognitive dysfunction as vaccination with human fA $\beta 42$ [12]. The immune response to this oligomer mimic antigen results in the production of antibodies that recognize generic epitopes in prefibrillar oligomers independent of the precise amino acid sequence. Indeed, vaccination of rabbits with islet amyloid polypeptide (IAPP) oligomer mimics results in the production of an immune serum that specifically recognizes a variety of prefibrillar amyloid oligomers but not fibrils and is indistinguishable from the serum produced in response to vaccination with $A \beta$ oligomer mimics [13]. This indicates that vaccination with the prefibrillar oligomer (PFO) conformation of other peptides gives rise to antibodies that recognize $A \beta$ PFOs, suggesting that vaccination with a non-human random peptide sequence that also forms PFOs would also give rise to this generic PFO specific immune response. Recently, it was reported that vaccination of $\mathrm{Tg}$ mice with a 13 residue random sequence peptide derived from the carboxyl terminus of pABri (polymerized British amyloidosis peptide) related peptide reduces amyloid pathology and preserves cognitive function in APP/PS1 transgenic mice [14]. Here we report that vaccination with a random sequence $\mathrm{PFO}$ antigen gives rise to a generic PFO specific immune response that recognizes $A \beta$ oligomers and that vaccination of $\mathrm{Tg}$ mice with this antigen is as effective in reducing amyloid deposition and preserving cognitive function. The use a non-human amyloid oligomer as a vaccine may overcome potential problems with auto inflammatory side effects observed with human $A \beta$.

\section{Results}

Identification of a random peptide sequence that forms A11 positive prefibrillar oligomers

We synthesized a series of 20 random sequence peptides from a restricted set of 8 amino acids and tested their ability to form prefibrillar oligomers by dot blot analysis with A11. Of these peptides, only 10 were sufficiently soluble to work with. One of these sequences, 3A, formed oligomers that react strongly with A11. We prepared 3A oligomer mimetic antigen by coupling 3A to colloidal gold particles and vaccinated rabbits with this immunogen. Serum from $3 \mathrm{~A}$ vaccinated rabbits and A11 was used to probe dot blots containing $A \beta$ monomer, $A \beta$ prefibrillar oligomers, $A \beta$ fibrils, calcitonin prefibrillar oligomers, IgG light chain prefibrillar oligomers and synthetic KK(Q40)KK prefibrillar oligomers. Like A11, which is raised against $A \beta$ oligomer mimic antigen, serum from $3 A$ vaccinated rabbits reacted with all prefibrillar oligomer samples, including $A \beta$, but not $A \beta$ monomer or $A \beta$ fibrils (Figure 1). No immunoreactivity was observed for preimmune serum from the rabbit immunized with $3 \mathrm{~A}$ oligomers. These results demonstrate that vaccination with a non-human random peptide sequence oligomer mimic give rise to an immune response that recognizes many different types of prefibrillar oligomers, including $A \beta$ and are consistent with our previous observations that serum from rabbits vaccinated with IAPP oligomer mimics is indistinguishable from A11 [13].

\section{Immune response in Tg2576 mice vaccinated with prefibrillar oligomer mimics and fibrillar $A \beta$}

To evaluate the therapeutic effectiveness of the $3 \mathrm{~A}$ antigen, we immunized $\operatorname{Tg} 2576$ mice with $3 \mathrm{~A}, \mathrm{~A} \beta$, and IAPP oligomer mimetics and $A \beta$ fibrils. Mice were immunized at monthly intervals beginning at 3 months up to 14 months. We performed ELISA assays to analyze the reactivity of the sera obtained from all groups of immunized mice against monomeric $\mathrm{A} \beta$, $\mathrm{A} \beta$ PFOs, IAPP PFOs, 3A PFOs and A $\beta$ fibrils (Figure 2). For all vaccinated groups, the highest reactivity is observed for the antigen they were immunized with. In addition, generic reactivity for prefibrillar oligomers samples is observed in the groups immunized with prefibrillar oligomer mimics. The immune response to the $3 \mathrm{~A}$ peptide oligomer vaccine was specific for prefibrillar oligomers and did not display significant reactivity to monomeric or fibrillar $A \beta$ (Figure 2). In contrast, the serum from $A \beta$ fibrillar vaccinated mice shows immunoreactivity with 


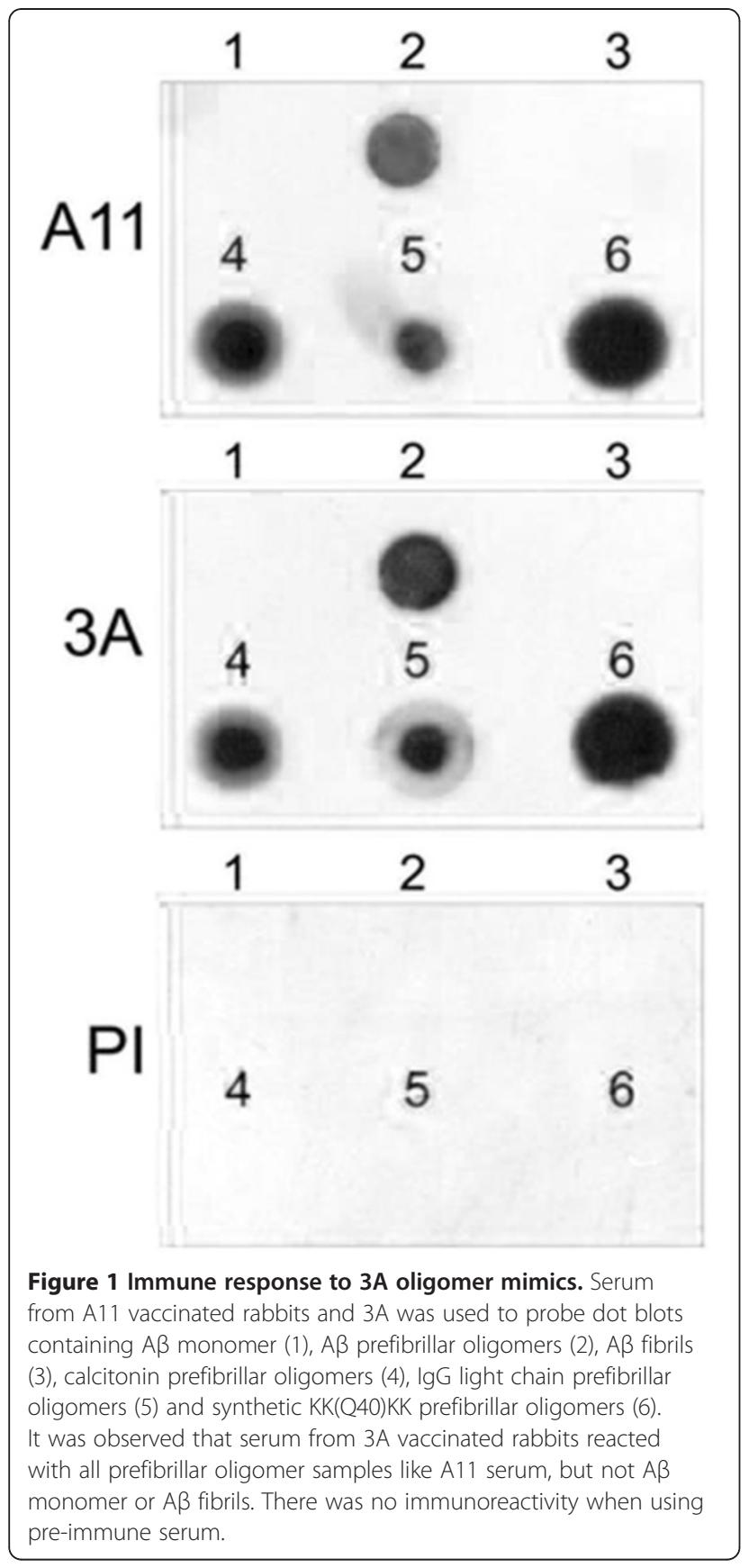

$A \beta$ fibril and $A \beta$ PFOs (Figure 2). It shows that immunization with $A \beta$ fibrils produced antibodies that reacted primarily with their own antigen and displayed some cross-reactivity with $A \beta$ PFOs. Cross-reactivity could be due to small quantities of fibril-like structures in the PFO sample or small amounts of antibodies against PFOs in the serum. The titer of each vaccinatedgroup is expressed as the $\log 10$ of the IC50 values to normalize the distribution and statistical analysis on the transformed values has been done accordingly. As a result all the vaccinated groups, including IAPP oligomer, showed a significant immune response not only against their own antigen, but also against oligomers as compared to non-vaccinated mice. Control vaccinated mice displayed very low titers $(<50)$ towards all antigens. None of the mice developed significant quantities of antibodies that react with $A \beta 40$ monomer. These results indicate that the antibodies developed by the immunized mice in response to both $A \beta$ fibrils and oligomers are predominantly conformation-dependent, aggregation specific and recognize generic epitopes that are independent of the precise amino acid sequence.

\section{Vaccination with $3 \mathrm{~A}$ oligomer mimics improves cognitive performance}

We evaluated the reference memory of $\operatorname{Tg} 2576$ mice at the age of 14 months in a Morris water maze test. At the age of 14 months, mice were trained on the spatial reference version of the Morris water maze task after 11 months of vaccination. $3 \mathrm{~A}$ peptide, $\mathrm{A} \beta$ oligomer, $\mathrm{A} \beta$ fibril and IAPP oligomer vaccinated mice all demonstrate a significant improvement $(* * \mathrm{p}<0.001)$ in behavioral acquisition and retention in Morris Water Maze (Figure 3A). At 90 minutes and $24 \mathrm{~h}$ in probe trials with the platform removed, mice immunized with $A \beta$ oligomer, IAPP oligomer, $3 \mathrm{~A}$ oligomer mimics and $\mathrm{A} \beta$ fibrils show significant improvement $(* * * \mathrm{p}<0.001)$ in memory retention on the latency to cross the platform location and the number of platform crosses during 90 minute and $24 \mathrm{~h}$ tests as compared to controls (Figure 3B). Contextual learning and memory was evaluated using the passive inhibitory avoidance task (Figure 3C). Passive avoidance memory retention (mean \pm S.E.M.) as measured by the ability of mice to remember an electrical shock after 24 hrs. Passive-avoidance tests were carried out in $\operatorname{Tg} 2576$ mice at 14 months of age. In the first acquisition trial of the learning stage, all mice (14 months old) entered the dark compartment immediately after being placed in the illuminated compartment. In retention trials the step-through latency of the immunized mice with $A \beta$ oligomer, IAPP oligomers and $3 \mathrm{~A}$ oligomer mimics was significantly increased (" $\mathrm{p}<0.05$ for $\mathrm{A} \beta$ oligomer and ${ }^{* * *} \mathrm{p}<0.001$ for IAPP and $3 \mathrm{~A}$ peptide, ) as compared to that of the control immunized group (Figure 3C). We evaluated visual recognition memory at the ages of 14 months in a novel object recognition test (Figure 3D). This test is believed to be primarily dependent on cortex. The time that the mice explored the novel object versus the familiar object is called the recognition index (RI). 50\% RI means that mice are not specifically interested in either of the objects. At 14 months, $\operatorname{Tg} 2576$ mice immunized with 3A oligomer mimics vaccinated mice shows statistically significant improvement in novel object recognition memory at both $1.5 \mathrm{hrs}$ and $24 \mathrm{hrs}(3 \mathrm{D})$, to control vaccinated mice ("p $<0.05)$. 


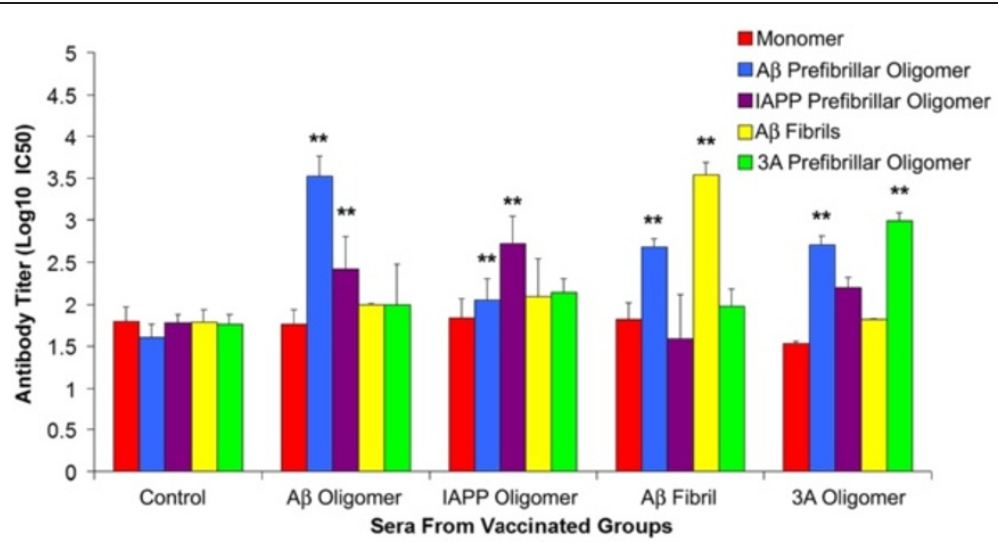

Figure 2 Characterization of the immune response in vaccinated Tg2576 mice. Antibody titers against $A \beta$ monomer, $A \beta$ prefibrillar oligomer, IAPP prefibrillar oligomer, A $\beta$ fibril and 3A prefibrillar oligomer were determined for all the vaccinated groups by ELISA. Each vaccinated group showed significant immune response against its respective antigen as compared to the control vaccinated group. Values represent the average titer (mean $\pm \mathrm{SD})$ from the sera of 6 individual mice in each group $(* * p<0.01)$.

Immunization with $3 A$ oligomer mimics reduces $A \beta$ plaque accumulation in Tg2576 mice

Vaccination against fibrillar $A \beta$ is known to reduce plaque deposition in transgenic animals [10]. Amyloid deposition in 14 months Tg2576 mice was assessed using the human $\mathrm{A} \beta$ specific monoclonal antibody, $6 \mathrm{E} 10$. We compared the effectiveness of the immunization on amyloid deposition by quantifying the amount of

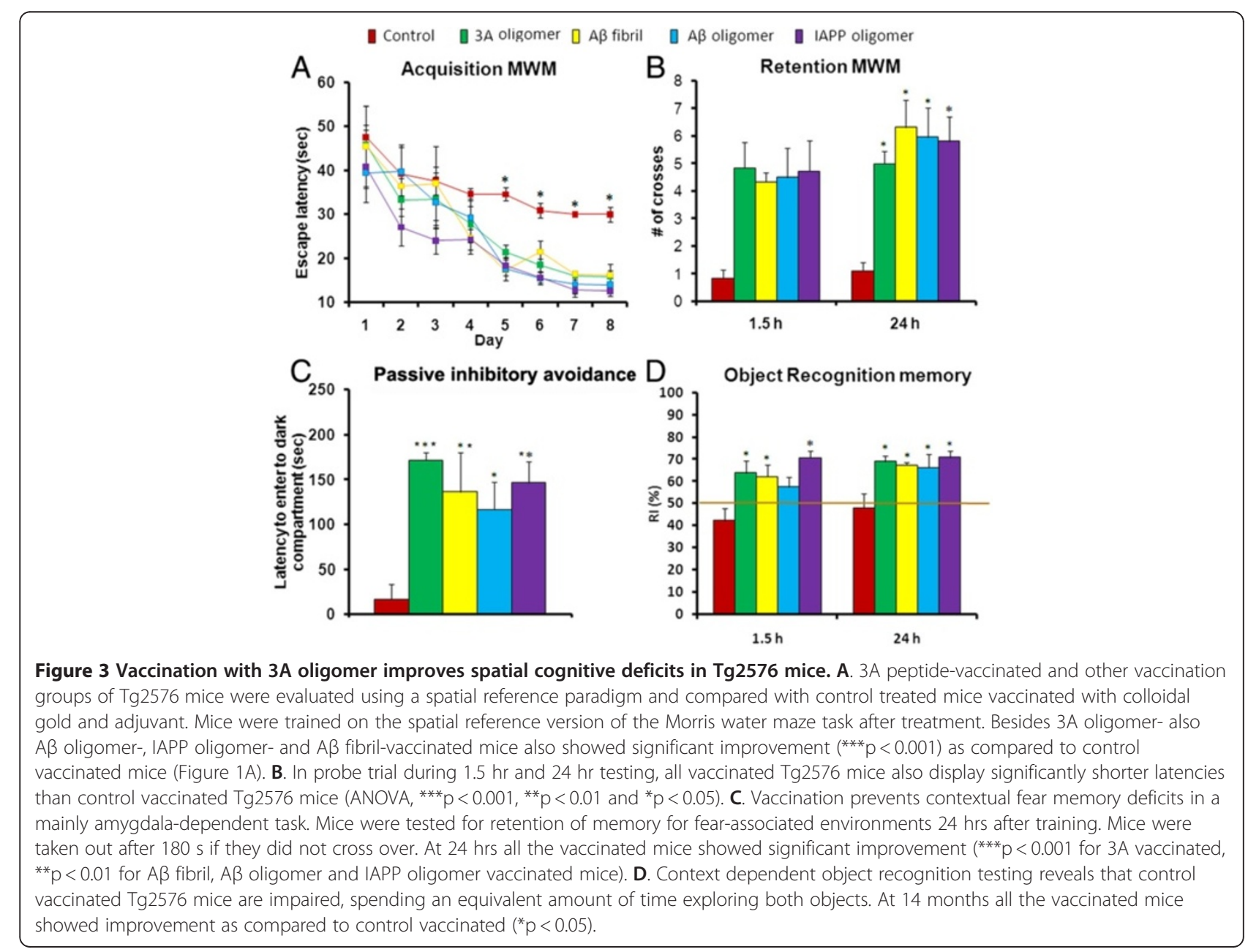


anti- $A \beta$ (6E10) immunoreactive material. Figures 4A show representative photomicrographs from the hippocampus and cortex of control and immunized animals. Image analysis of sections from multiple animals demonstrated that $\mathrm{A} \beta$ deposits in $\mathrm{A} \beta$ oligomer, IAPP oligomer, $3 \mathrm{~A}$ oligomers mimics and $\mathrm{A} \beta$ fibril immunized mice were decreased significantly as compared to control vaccinated group. (Figure 4B) shows that all the immunized groups displayed a significant reduction in $A \beta$ plaque load in both hippocampus and cortex as compared to the respective controls ( $\left.{ }^{*} \mathrm{p}<0.05,{ }^{* *} \mathrm{p}<0.01\right)$.

\section{Immunization with $3 \mathrm{~A}$ oligomer mimics reduces soluble and insoluble levels $A \beta 40$ and $A \beta 42$}

To evaluate whether vaccination with $3 \mathrm{~A}$ peptide oligomer not only reduced plaque load but also affected cerebral total $\mathrm{A} \beta$ levels, brain homogenates were processed to prepare insoluble amyloid deposits. Subsequently, A $\beta$ levels were quantified using a highsensitivity sandwich ELISA measuring $A \beta 40$ and $A \beta 42$ separately as described in methods. Consistent with the reduced plaque by $3 \mathrm{~A}$ oligomer mimics, we observed a significant reduction in soluble and insoluble levels of
$\mathrm{A} \beta 40$ and $\mathrm{A} \beta 42$ (Figure 5). In $\mathrm{A} \beta$ fibril vaccinated mice, the insoluble levels of $A \beta 40$ were not significantly decreased as compared to other groups, where as insoluble A 342 levels were significantly decreased. Immunization with the $3 \mathrm{~A}$ peptide oligomer mimic antigen induces an immune response that significantly reduced insoluble levels of cerebral $A \beta 40$ and $A \beta 42$.

\section{Immunization with 3A Oligomer mimics reduces microglial activation}

Microglia play a major role in regulating homeostasis in the brain and have the ability to activate phagocytose, secrete cytokines, and to present antigens to $\mathrm{T}$ cells depending on their stimulatory environment [15]. However, some of these same neuroprotective functions are detrimental if dysregulated [16]. One of the main characteristics accompanying accumulation of $A \beta$ plaques in both human Alzheimer's brain and transgenic mouse models of $\mathrm{AD}$ is an enhanced neuroinflammatory response characterized by activation of microglia. It has been previously reported that immunization with $A \beta$ reduces the microglial activation [12]. We assessed the effect of immunization by $3 \mathrm{~A}$ oligomer mimics on
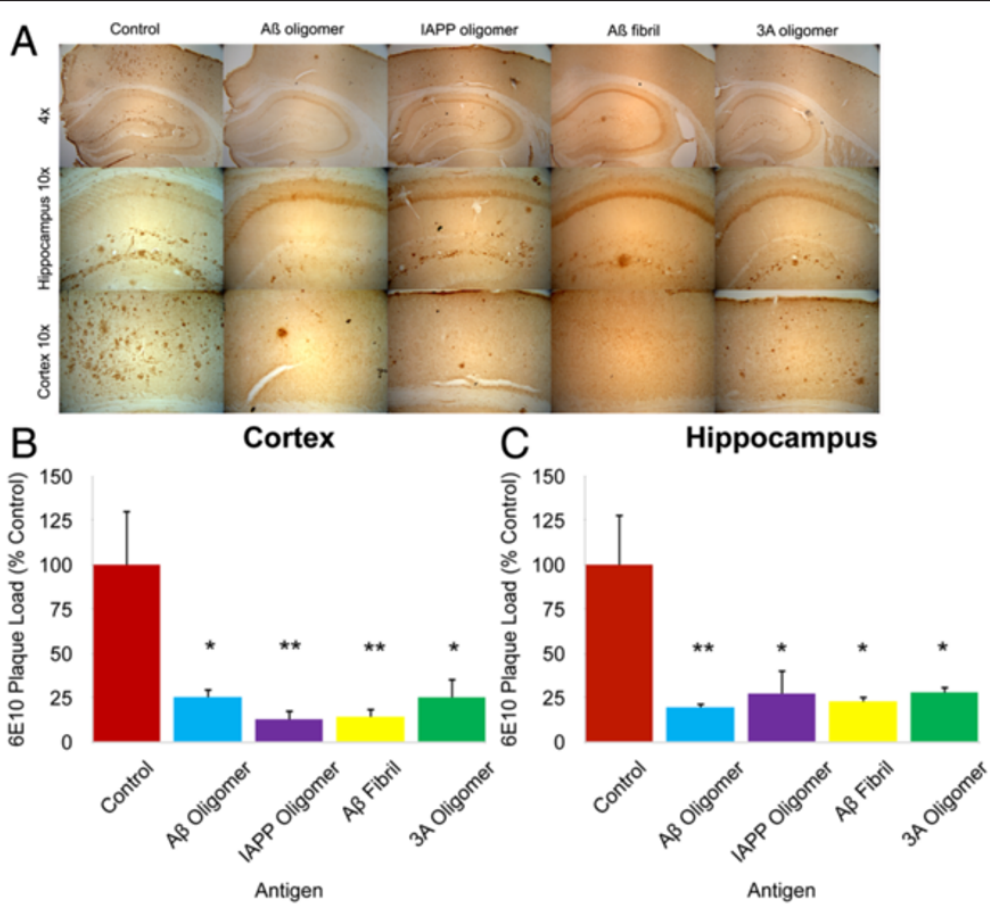

Figure 4 Immunization initiated at 3 months of age in Tg2576 animals decreases total amyloid deposits. A. Representative photomicrographs of sections from brains (hippocampus and cortex) of 14 months Tg2576 (Control, A oligomer, IAPP oligomer, 3 A peptide and A $\beta$ fibril) that have been vaccinated as described in materials \& methods from 3 to 14 months of age immunostained with 6 E10 (which reacts with the human amyloid peptide). Scale bar: 100 microns B. Quantitation of plaque load. Image analysis (\% Field area) of AB (6E10 antibody) immunoreactivity in hippocampus and cortex of immunized animals at 3-14 months is expressed as \% of untreated control mice. The mean value for each animal was determined as the average of 2 sections (except untreated control which is 1 section per animal) using 4-8 images per section (most to all of the area of the section was analyzed). Bars represent group mean \pm SEM of $n$ mice per group: Control $n=8$, $A \beta$ oligomer $n=8$, IAPP oligomer $n=8$, 3A oligomer mimic $n=8$ and A fibril $n=6$, ${ }^{*} p<0.05$ and ${ }^{* *} p<0.01$ by ANOVA (B). 

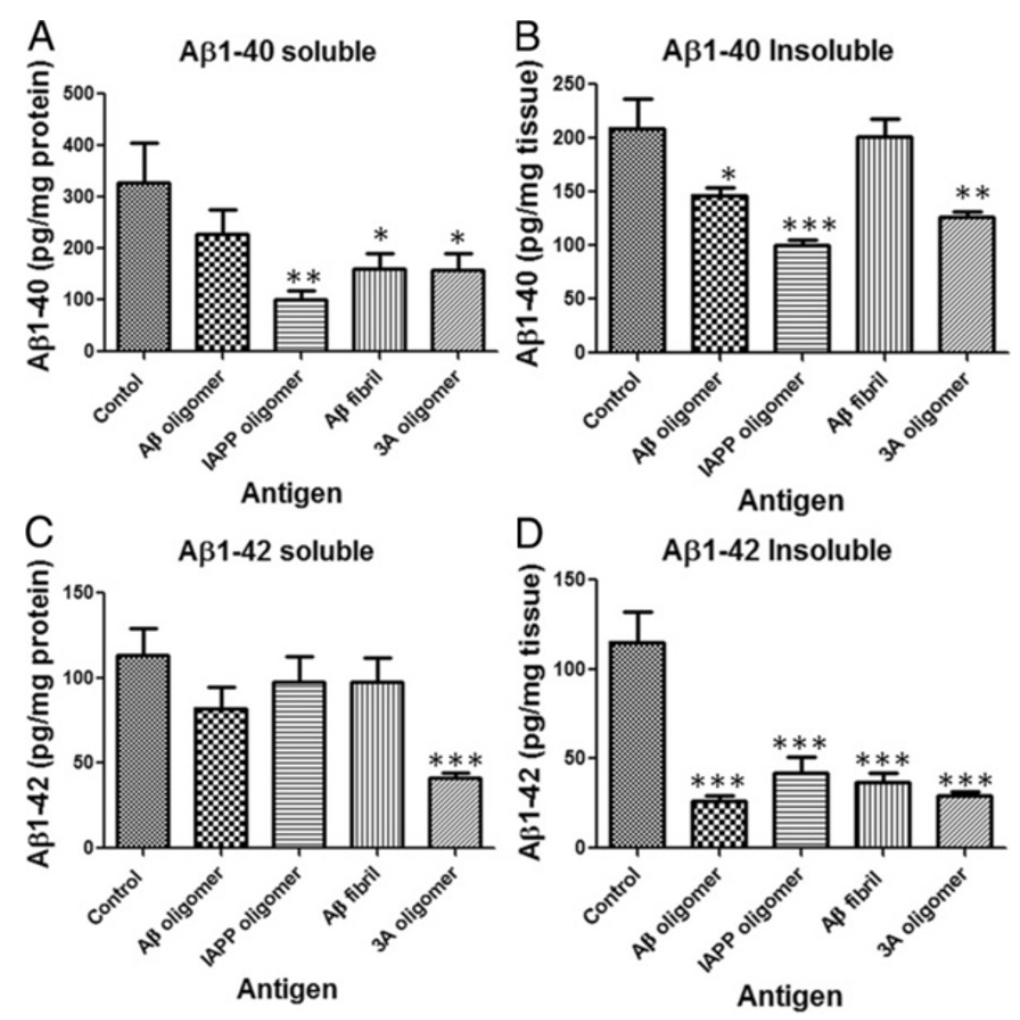

Figure $\mathbf{5}$ Vaccination with $3 \mathbf{A}$ oligomer mimic strongly reduces levels of $\mathbf{A} \beta \mathbf{4 0}$ and $\mathbf{A} \beta \mathbf{4 2}$ in brain. Following 3-14 months of treatment, levels of soluble and insoluble levels $A \beta 40$ and $A \beta 42$ on homogenates of the whole brain hemisphere of $\operatorname{Tg} 2576$ mice were determined by ELISA. 3A peptide treatment waswas associated with significantly lower levels of both soluble and insoluble $A \beta 40$ and $A \beta 42$. The insuluble levels were represented in $\mathrm{pg} / \mathrm{mg}$ of tissue. Error bars represent standard errors of the mean $(n=8)$. ${ }^{*} p<0.05$ for soluble levels of $A \beta 40,{ }^{*} p<0.01$ for soluble and insoluble levels of A 342 , by one-way ANOVA test.

microglial reactivity as measured by $\mathrm{CD} 45$ immunohistochemistry (Figure 6A). All the immunized groups displayed a significant decrease in CD45 immunostaining relative to the respective controls $(* * * * 0<0.001)$ (Figure 6B).

\section{GFAP reactivity is decreased in $3 \mathrm{~A}$ oligomer mimics vaccinated mice}

Activation of astrocytes is another characteristic feature of amyloid deposition. It has been observed that activated astrocytes are reduced in the same proportion as the amyloid by immunization with $A \beta$ [12]. To assess the involvement of activated astrocytes following vaccination, immunohistochemical analysis of GFAP, a marker for astroglia was performed. Quantitative analysis showed that there was a significant reduction in GFAP immunoreactivity. 3A peptide oligomer mimic immunized mice display a significant reduction of activated astrocytes in the hippocampus and cortex (Figure 7A-J). The quantification was statistically significant as compared to controls $(* \mathrm{p}<0.05)$. Activated astrocytes were also significantly decreased in hippocampus of mice vaccinated with $A \beta$ oligomer and IAPP oligomer, however in cortex there was no significant decrease. The explanation for this difference may be that in $A \beta$ oligomer and IAPP oligomer vaccinated mice where we observed a decrease in cortical plaques, there is GFAP immunoreactivity that is not associated with plaques.

\section{Microhemorrhage is reduced in $3 \mathrm{~A}$ oligomer} mimics and IAPP oligomer vaccinated mice

An increased incidence of micro hemorrhage has been observed in both active and passive Aß immunotherapy [17]. We therefore investigated the incidence of micro hemorrhage in the vaccinated and control animals. The method we used categorizes micro hemorrhages in 4 different stages of increasing size and vessel involvement [18]. The number of micro hemorrhages per section is reported in Table 1 for each stage. As previously reported, most of the micro hemorrhages observed in $A ß$ vaccinated $\operatorname{Tg} 2576$ animals were stage 1 , consisting of 1 to 5 grains of iron or small vessel involvement and are shown in Figure 8A. We found that the 3A and IAPP vaccinated mice showed a striking reduction in 


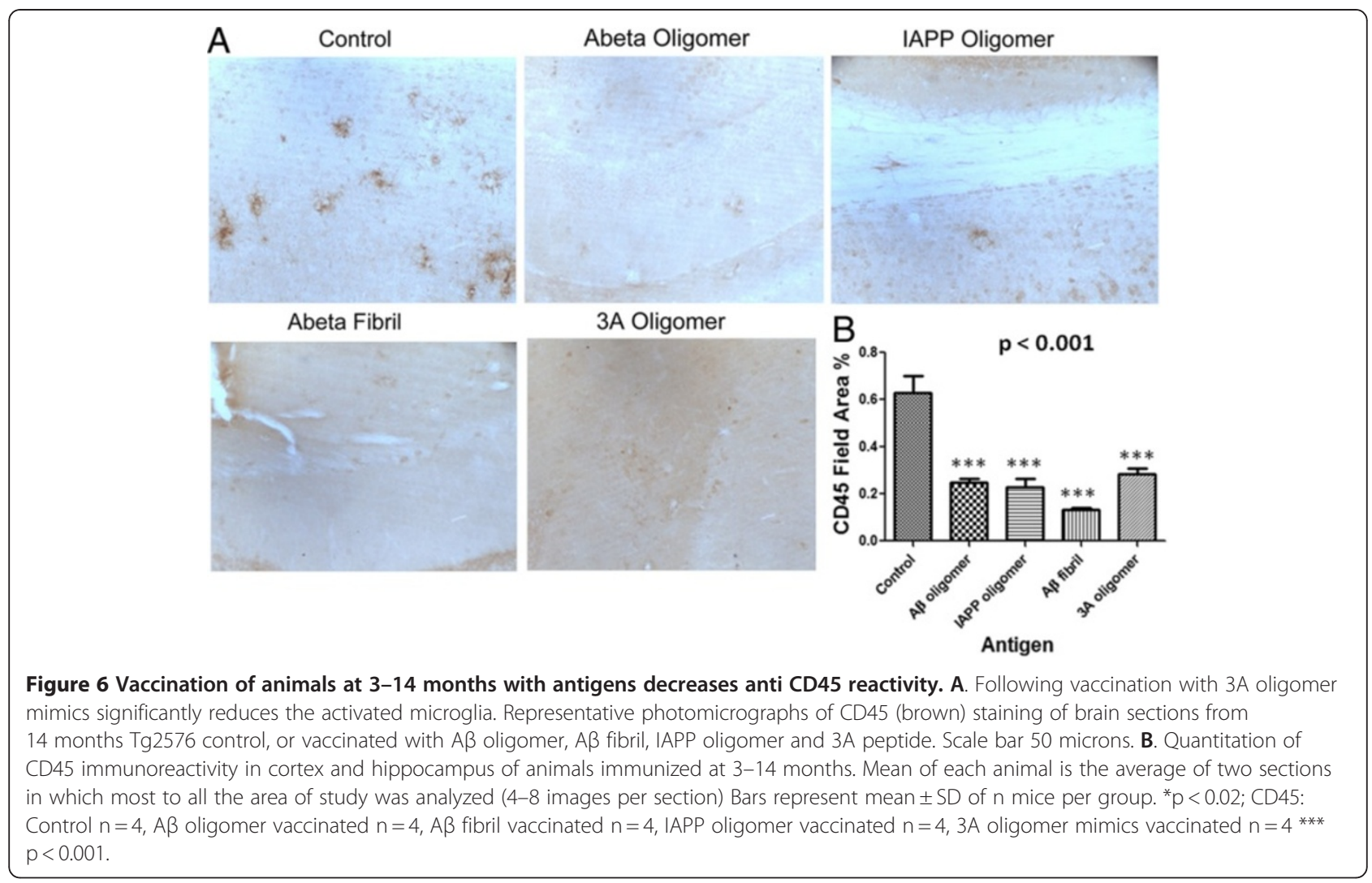

parenchymal iron deposition consistent with a lower incidence of micro hemorrhages compared to the $A \beta$ oligomer and $A \beta$ fibril vaccinated groups $\left({ }^{* * *} \mathrm{P}<0.001\right)$ (Figure $8 \mathrm{~B}$ ). The $3 \mathrm{~A}$ and IAPP vaccinated groups were not statistically different from the control vaccinated group. Stage 2 micro hemorrhages, consisting of multiple grains of iron and micro vessel involvement were also significantly elevated in the $A ß$ fibril and $A ß$ oligomer vaccinated groups (Table $1, \mathrm{P}<0.001, \mathrm{P}<0.05$ respectively). Stage 3 micro hemorrhages, consisting of several positive micro vessels in 1 area, were significantly elevated only in the Aß fibril vaccinated group. Stage 4 micro hemorrhages with large blood vessel involvement were rarely observed in the $A ß$ vaccinated groups and none were observed in the control, $3 \mathrm{~A}$ and IAPP vaccinated groups although this difference did not reach statistical significance. In $A ß$ vaccinated fibril and oligomer groups, micro hemorrhages were observed in the somatosensory and auditory cortices, the CA1, CA3 and dente gyrus of the hippocampus, lateral and ventral hypothalamic areas, and the ventral posterior medial thalamic nucleus. No preferential localization of micro hemorrhages in a specific brain area was observed for any groups. These results indicate that the non- $\mathrm{A} \beta$ antigens may have a better safety profile with respect to micro hemorrhage than $A \beta$ containing antigens.

\section{Discussion}

Anti-A $\beta$ immunotherapy is currently one of the leading strategies for $\mathrm{AD}$ therapeutic development with several vaccines in human clinical trial $[2,19]$. Numerous pre-clinical studies with mouse models of $\mathrm{AD}$ have demonstrated the ability of $A \beta$ vaccination to prevent amyloid deposition in the brain. Thus, active immunization with $A \beta[10,20]$, as well as passive immunization [15-17,19-27] resulted in a reduction of the amyloid burden in the brain. Importantly, active immunization prevented cognitive decline $[28,29]$ and passive immunizations were shown to reverse the memory loss in aged Tg2576 mice [30]. While these and other studies did not report any adverse events in AD transgenic mouse models immunized with fibrillar $\mathrm{A} \beta 42$, data from the AN1792 vaccine trial reported meningoencephalitis in $6 \%$ of the patients. These adverse reactions to $A \beta 42-$ immunotherapy appear not to be due to the humoral antibody response, but rather to the cell-mediated autoimmune response which induced a Th1 type immune response in patients that received the AN1792 vaccine [31-37]. Thus, the goal of this pre-clinical study was to investigate the effectiveness of a non human random peptide (oligomer mimic), that induces a Th2-type humoral immune response specific to oligomeric $A \beta$ peptide, but would not be expected to cause Th1 auto inflammatory side effects because the antigen is non-human. 

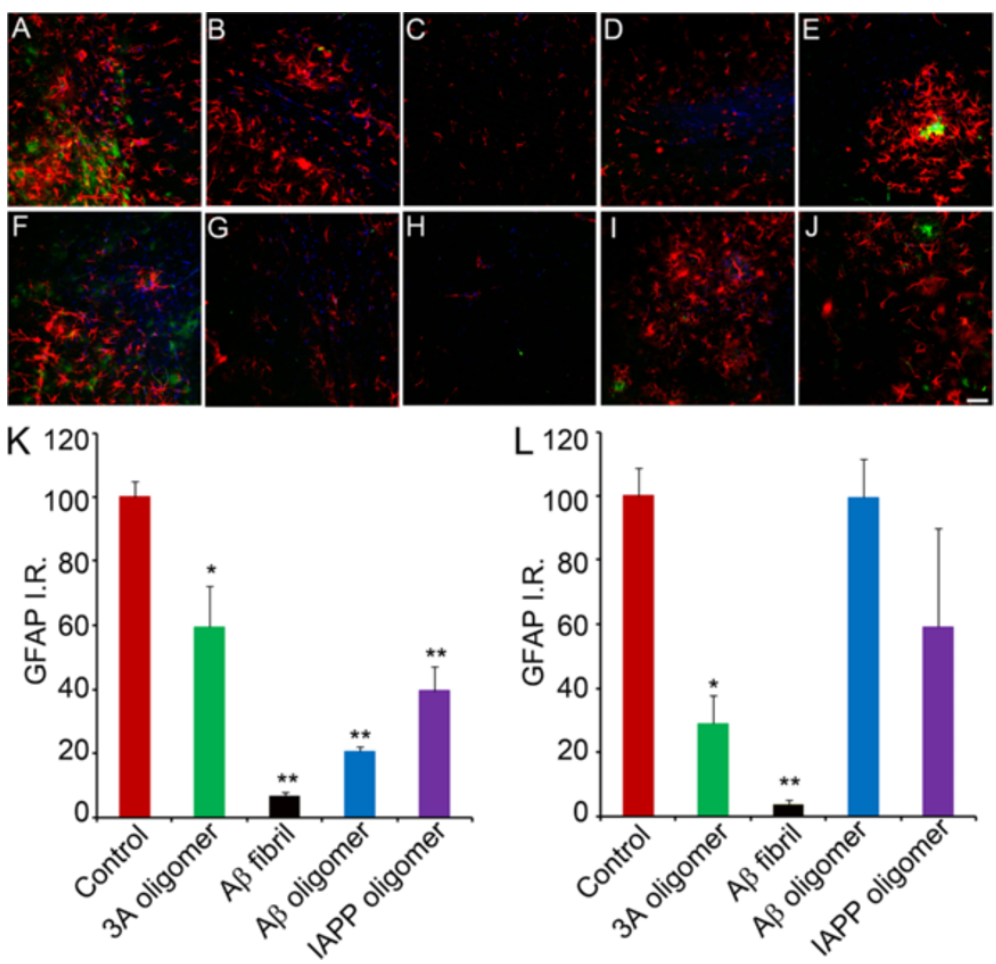

Figure 7 Activated astrocytes surrounding A $\beta$ plaques are decreased in Tg2576 mice following vaccination. Astrocyte reactivity (GFAP, red) preferentially associates with Aßplaques (6E10, green) and is reduced in the hippocampus (A-E) and cortex (F-J) of Tg2576 mice following immunization with PBS control $(\mathbf{A}, \mathbf{F})$, 3 A oligomer mimics $(\mathbf{B}, \mathbf{G}), \mathrm{A} \beta$ fibrils $(\mathbf{C}, \mathbf{H})$, A $\mathrm{\beta}$ oligomers (D, I), and IAPP oligomers (E, J). Cell nuclei were stained with DAPI (blue). Scale bar $=100 \mu \mathrm{m}$. Quantifications of GFAP immunoreactivity in the hippocampus (K) and cortex (L) demonstrate significant astrocytosis reduction in mice vaccinated with $3 \mathrm{~A}$ and $A \beta$ fibrils. Error bars represent standard errors of the mean ( $n=3$ ). ${ }^{*} p<0.05,{ }^{*}$ $p<0.001$ by one-way ANOVA test.

The data presented here indicate that immunization with non-human 3A amyloid random sequence oligomer produces an efficacious immune response in a murine model of $\mathrm{AD}$ that is comparable to that of mice immunized with fibrillar $A \beta 42$ and $A \beta 40$ oligomer mimics. We tested escape latency, number of platform crosses in the Morris water maze test (MWM) (which is related to hippocampus), novel object recognition (which is related to cortex) and inhibitory avoidance (which is related to amygdala). It was found that at 14 months, 3A oligomer mimic vaccinated mice have a significant improvement in cognitive function compared to controls. We examined the effect of immunization on the neuropathology

Table 1 Microhemorrhage foci observed per section

\begin{tabular}{|c|c|c|c|c|}
\hline Group & Stage 1 & Stage 2 & Stage 3 & Stage 4 \\
\hline Control & 0.9 & 0.5 & 0 & 0 \\
\hline $3 A$ & 1.7 & 0.2 & 0 & 0 \\
\hline IAPP & 1.0 & 0.1 & 0 & 0 \\
\hline Aß oligomer & $6.9^{* * *}$ & $1.6^{*}$ & 0.6 & 0.4 \\
\hline Aß fibril & $7.6^{* * *}$ & $2.5^{* * *}$ & $0.9^{* * *}$ & 0.3 \\
\hline
\end{tabular}

Statistical significance in comparison to control, 3A and IAPP groups: *** $\mathrm{P}<0.001$.

$* \mathrm{P}<0.05$. in 14 months old mice, and showed a significant reduction in plaques in both cortex and hippocampal region immunized with $3 \mathrm{~A}$ peptide. The ELISA data shows that the reduction in insoluble $\mathrm{A} \beta 42$ is modest (approximately 40\%) and mostly absent for $A \beta 40$ in the fibril vaccinated group, while we observed a more robust (approximately $80 \%$ ) decrease in plaque burden as determined by 6 E10 immunoreactivity by IHC. The explanation for this apparent discrepancy is not clear, but it may be due to the fact that the ELISA measures the amount $A ß$ while the immunohistochemistry measures area of the plaque. This may be a reflection of a change of state of the amyloid in the fibril vaccinated group to a more compact or dense state rather than its removal.

These results are consistent with recent findings that vaccination against a random sequence peptide encoded by read through of a stop codon in the pABri mRNA improves cognition and reduces plaques in APP/PS1 mice [14]. Mice immunized with the ABri random peptide produced antibodies that recognize aggregated $\mathrm{A} \beta$, reduced plaque deposition and improve cognition, similar to the results we report here. However, the immune response to this antigen is broader and includes 


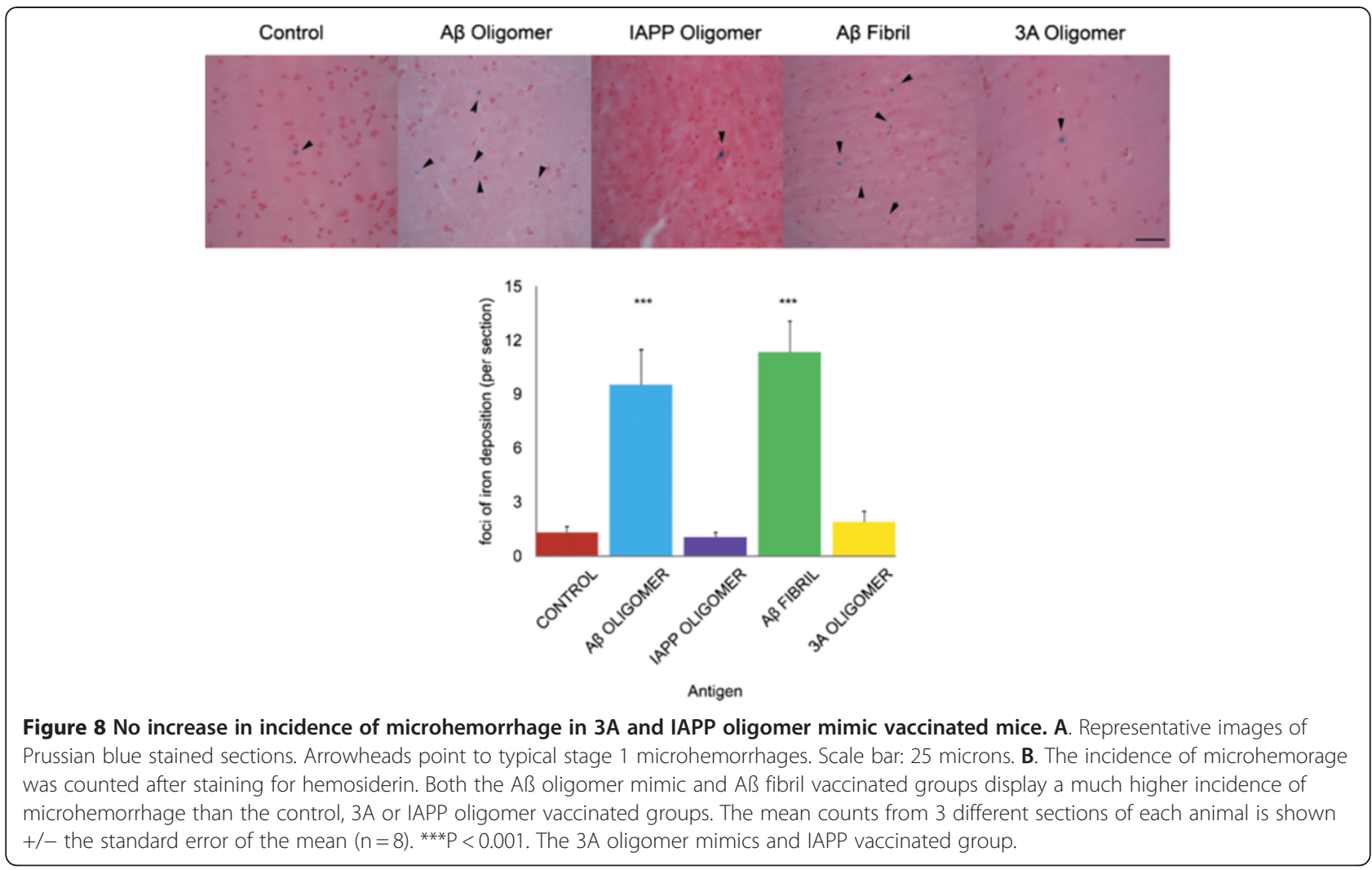

antibodies that react with neurofibrillary tangles and plaques. Together with our results with the $3 \mathrm{~A}$ random sequence antigen, these results provide strong support to the concept that targeting generic epitopes associated with $A \beta$ aggregates is therapeutically effective. Small but significant levels of this type of antibodies exist in nonvaccinated humans and the levels of these antibodies are inversely correlated with the incidence of AD [38]. These conformation-specific, sequence-independent antibodies are the major antibodies against $A \beta$ that exist in normal human plasma [38] and these antibodies may account for the reported effectiveness of IVIg in reducing the incidence of AD in humans [39]. IAPP oligomer and $3 \mathrm{~A}$ oligomer mimics vaccinated mice showed a relatively low titer as compared to $A \beta$ oligomer and $A \beta$ fibril vaccinated groups, yet retaining their efficacy in preventing cognitive deficits and amyloid deposition. Increasing evidence suggests a role for amyloid oligomers as the toxic species responsible for disease progression and pathogenesis independently of the plaque load [14]. In this view, our results suggest that effective targeting of toxic species rather than the overall extent of immune response elicited may be relevant. The higher titer observed for either $A \beta$ oligomer and $A \beta$ fibril vaccinated groups may therefore reflect the recognition of a broader range of aggregated conformations.
There is increasing evidence that $A \beta$ oligomers and fibrils are conformationally and structurally diverse [40-42], which raises the issue of whether the different conformers are differentially associated with pathogenesis [43]. Because monoclonal antibodies recognize these conformers in a mutually exclusive fashion $[44,45]$, a single antibody may not be able to target all of the pathologically significant forms of $A \beta$. The polyclonal response to active immunization is broad, suggesting that it may be more beneficial in its ability to target more different conformers of $A \beta$ than a single monoclonal [45]. A potential advantage of vaccination against conformation dependent epitopes is that the resulting antibodies are specific for aggregated forms of $A \beta$ and do not react with $A \beta$ monomer or APP $[13,40]$. This suggests that these antibodies may have a better pharmacological profile than antibodies that recognize APP, which is abundantly expressed or $A \beta$ monomer which is a normal product of APP processing and may have normal roles that should not be interfered with. The lack of reactivity with normal human proteins would also be expected to provide a lower potential for autoimmune complications as well.

We also found that the non- $\mathrm{A} \beta$ antigens, $3 \mathrm{~A}$ and IAPP were associated with a much lower incidence of micro hemorrhage than the $A \beta$ oligomer and $A \beta$ fibril groups. Since the conformation dependent immune response 
to $A \beta$ oligomer and $A \beta$ fibril antigens are distinct while the immune response to the oligomer mimic antigens is common $[13,40]$, this suggests that the increased incidence of micro hemorrhage may be due to sequence specific antibodies that are common to the $\mathrm{A} ß$ containing antigens. This reduced incidence of micro hemorrhage may also contribute to a superior safety profile of the random sequence oligomer antigen, like 3A.

These results demonstrate that vaccination against generic amyloid oligomer epitopes is capable of attenuating cognitive impairment and producing a protective immune response without increasing the incidence of micro hemorrhage, suggesting that vaccination against a nonhuman amyloid oligomer epitope may be a safer therapeutic strategy for developing an effective vaccine that circumvents auto inflammatory immune complications.

\section{Materials and methods}

\section{Preparation of random peptides}

We synthesized a series of 8 random sequence 20mers using a restricted set of 8 amino acids, threonine, tyrosine, serine, histidine, isoleucine, valine, phenylalanine and leucine. The sequences of the 20mers were randomly drawn and checked against the human nonredundant protein sequence data base with BLAST to select for sequences that had the lowest homology with human protein sequences. The sequences were synthesized and tested for the ability to form prefibrillar amyloid oligomers using the A11 prefibrillar oligomer specific polyclonal antibody. One of the sequences (peptide 3A: TYLIHVHIITIYHISIYYIV) formed A11 positive oligomers in a time dependent fashion and was selected for further analysis.

\section{Oligomer mimic antigens}

$\mathrm{A} \beta$, IAPP and $3 \mathrm{~A}$ peptide oligomer molecular mimic antigens were prepared by synthesizing carboxylterminal thiol derivatives and coupling them to colloidal gold particles as previously described [46].

\section{Preparation of $A \beta$ prefibrillar oligomers and fibrils}

A 340 peptides were lyophilized in 50\% acetonitrile/ $\mathrm{ddH}_{2} \mathrm{O}$. Soluble oligomers were prepared by dissolving $1.0 \mathrm{mg}$ of peptide in 400ul hexafluoroisopropanol (HFIP) for $10-20 \mathrm{~min}$ at room temperature. $100 \mu \mathrm{l}$ of the resulting seedless solution was added to $900 \mu \mathrm{lmilliQ} \mathrm{H}_{2} \mathrm{O}$ in a siliconized Eppendorf tube. The samples were then stirred at 500 RPM using a Teflon coated micro stir bar for $24-48 \mathrm{~h}$ at $22^{\circ} \mathrm{C}$. The samples were centrifuged for $15 \mathrm{~min}$. at $14,000 \times \mathrm{G}$ and the supernatant fraction (pH 2.8-3.5) was transferred to a new siliconized tube and subjected to a gentle stream of $\mathrm{N}_{2}$ for 5-10 min to evaporate the HFIP. Formation of oligomers were confirmed by atomic force microscopy (AFM), electron microscopy (EM) and size exclusion chromatography (SEC) as described [40]. Fibrils were formed by dissolving $\mathrm{A} \beta 42$ in $50 \% \mathrm{HFIP} / \mathrm{ddH}_{2} \mathrm{O}$ and stirred with closed caps for 7 days. Solution was stirred again for 2 days using open caps to evaporate the HFIP. Fibrils were sedimented, washed, and resuspended in PBS at $2 \mathrm{mg} / \mathrm{ml}$.

\section{Immunization}

New Zealand white rabbits were immunized with 3A oligomer mimics as previously described and the serum collected after significant titer against $A \beta$ oligomers was detected [46]. Preimmune serum was collected from the same rabbits prior to immunization. We immunized young $\operatorname{Tg} 2576$ mice (3 months old) [5] with one of the following antigens: $A \beta$ oligomer, IAPP oligomer, $A \beta$ fibril, random peptide $3 \mathrm{~A}$ oligomers or control with colloidal gold in PBS. The mice were equally distributed in each group of eight ( 4 males and 4 females). The antigens were mixed with incomplete Freund's adjuvant (1:1, $\mathrm{v} / \mathrm{v})$ and immunization was done subcutaneously (100 $\mu \mathrm{g} /$ immunization) every month up to 14 months. For controls a mixture of PBS and colloidal gold was used.

\section{Behavioral studies}

Three common tests for cognitive dysfunctions in AD model mice, the Morris Water Maze (MWM) [47,48] novel-object recognition $[48,49]$, and passive inhibitory avoidance tests [10], were performed according to previous reports with minor modifications.

\section{Morris water maze}

Morris water maze is a special memory task related to hippocampus. The apparatus used for all water maze tasks was a circular aluminum tank (1.5 m diameter) painted white and filled with water maintained at $26^{\circ} \mathrm{C}-$ $29^{\circ} \mathrm{C}$. The maze was located in a room containing simple visual, extra-maze cues. To reduce stress, mice were placed on the platform in both the hidden and cued versions of the task for $15 \mathrm{sec}$. prior to the first training trial. Mice were trained to swim to a circular clear Plexiglas platform (14 cm diameter) submerged $1.5 \mathrm{~cm}$ beneath the surface of the water and invisible to the mice while swimming. The platform location was selected randomly at 14 months test, but was kept constant for each individual mouse throughout training. On each trial, the mouse was placed into the tank at one of four designated start points in a pseudorandom order. Mice were allowed $60 \mathrm{sec}$. to find the submerged platform. If a mouse failed to find the platform within $60 \mathrm{sec}$., it was manually guided to the platform and allowed to remain there for 15 sec. After this, each mouse was placed into a holding cage under a warming lamp for $30 \mathrm{~s}$ before beginning the next trial. To ensure 
that memory differences were not due to lack of task learning, mice were given four trials a day for as many days as were required to train the Tg2576 mice to reach the criterion ( $<20 \mathrm{sec}$.). To control for overtraining, probe trials were run for each group, both as soon as they reached group criterion and after all groups had reached criterion. We trained the Tg2576 mice for 8 days at 14 months. Retention of the spatial training was assessed $1.5 \mathrm{hr}$ and again $24 \mathrm{hr}$ after the last training trial. Both probe trials consisted of a $60 \mathrm{~s}$ free swim in the pool without the platform. Mice were monitored by a camera mounted in the ceiling directly above the pool to record the $1.5 \mathrm{hr}$ and $24 \mathrm{hr}$ test. The parameters measured during the probe trial included initial latency to cross the platform location, number of platform location crosses, and time spent in the quadrant opposite to the one containing the platform during training.

\section{Novel object recognition}

The object recognition task used is based on the spontaneous tendency of rodents to explore a novel object longer than a familiar one. On day 1, the mice were allowed to familiarize themselves with the empty open field for 5 minutes. On day 2, they were subjected to a 5-minute exploration session of two identical, symmetrically placed objects A. Ninety minutes and 24 hours later, the animals were subjected to a 3-minute retention session where they were exposed to one object $\mathrm{A}$ and to a novel object B (after 90 minutes) or object C (after 24 hours). The times of exploration were recorded, and an object recognition index (ORI) was calculated, such that $\mathrm{ORI}=(\mathrm{tn}-\mathrm{tf}) /(\mathrm{tn}+\mathrm{tf})$, where $\mathrm{tf}$ and $\mathrm{tn}$ represent times of exploring the familiar and novel objects, respectively.

\section{Passive inhibitory avoidance}

Amygdala dependent task was evaluated using the passive inhibitory avoidance task [21], performed in the Gemini Avoidance System (San Diego Instruments, San Diego, CA). The training trial consisted of placing a mouse in the illuminated compartment of the device and recorded the latent time required for the mouse to enter the dark compartment (baseline latency). Upon entering the dark chamber, the door between the two compartments was closed and the animal was immediately given an electric shock to the feet $(0.15 \mathrm{~mA}, 1 \mathrm{~s})$. During the retention trials (conducted $1.5 \mathrm{~h}$ and $24 \mathrm{~h}$ after the training trial), the mouse was again placed in the illuminated compartment and the latency to enter the dark compartment was recorded. The retention trial was interrupted if the animal took more than $180 \mathrm{sec}-$ onds to cross into the dark compartment.

\section{ELISA analysis of anti $A \beta$ antibodies}

ELISA assays were performed as previously described [40]. Briefly, $200 \mathrm{ng} / 100 \mu \mathrm{l}$ of antigen (A $\beta$ oligomer, IAPP oligomer, $3 \mathrm{~A}$ oligomer mimic, $\mathrm{A} \beta$ fibril and $\mathrm{A} \beta$ monomer) was plated on ELISA wells and blocked with BSA. Serum samples were serially diluted to an end point of 1:100,000. The secondary antibody used for detection is peroxidase conjugated AffiniPure Goat Antimouse IgG $(\mathrm{H}+\mathrm{L})$ (Jackson ImmunoResearch). Titer was determined from the midpoint of the dilution curve (IC50).

\section{Tissue collection and immunohistochemistry}

After mice were anesthetized with pentobarbital (150 mg/kg, IP), blood was collected by cardiac puncture, and mice were perfused transcardially with cold phosphate-buffered saline (PBS). Brain tissues were fixed overnight with $4 \%$ paraformaldehyde in PBS, pH 7.4 at $4^{\circ} \mathrm{C}$ and stored in $\mathrm{PBS} / 0.02 \%$ sodium azide $\left(\mathrm{NaN}_{3}\right)$ at $4^{\circ} \mathrm{C}$ until use. Fixed brain tissues were sectioned $(40 \mu \mathrm{m})$ with a vibratome. Coronal sections were collected in PBS (containing 0.02\% sodium azide) and stored at $4{ }^{\circ} \mathrm{C}$ prior to staining. To stain for $\mathrm{A} \beta$ plaques, sections were immersed in $70 \%$ formic acid for $5 \mathrm{~min}$. Endogenous peroxidase in tissue was blocked by treating with $3 \% \mathrm{H}_{2} \mathrm{O}_{2}$ in PBS for $10 \mathrm{~min}$ at room temperature. Nonspecific background staining was blocked by $1 \mathrm{~h}$ incubation in $2 \%$ BSA, $0.3 \%$ Triton X-100 (TX) at room temperature. Tissues were incubated with primary antibodies (6E10, GFAP and CD45) overnight at $4^{\circ} \mathrm{C}$, rinsed 3 times with PBS,0.1\% TX, followed by biotinylated secondary antibodies (anti-rabbit, anti-mouse and anti-rat), detection with an $\mathrm{ABC}$ peroxidase kit, and visualization with a 3,3'-diaminobenzidine (DAB) substrate kit (Vector, Burlingame, CA). CD45 (Serotec, Raleigh, NC; 1:3000) staining was done as described previously [22]. Control experiments with primary or secondary antibody omitted resulted in negative staining.

\section{Immunohistochemical analysis}

Coronal brain sections were double-immunostained for astrocytes and $\mathrm{A} \beta$ plaques. Sections were permeabilized in $0.1 \%$ Triton X-100 for $15 \mathrm{~min}$ at RT, blocked in 5\% bovine albumin/PBS for 1 hour, and then probed with anti-mouse glial fibrillary acidic protein, GFAP (1:1000, Sigma), rabbit anti-fibril OC (1:4000) [13] for $24 \mathrm{~h}$ at RT. Fluorescent-conjugated secondary antibodies (antimouse, anti-rabbit Alexa, 1:400, Invitrogen Molecular Probes) were used for detection. Double immunofluorescent images were captured at a magnification of 10x and anayzed by the z-stack confocal microscopic system using Axio Vision (Zeiss). 


\section{Image quantification}

Immunostaining was observed under a Zeiss Axiovert200 inverted microscope (Carl Zeiss, Thornwood, NY) and images were acquired with a Zeiss Axiocam highresolution digital color camera (1300x1030 pixel) using Axiovision 4.1 or 4.6 software. The same software (Carl Zeiss) was used to analyze the digital images. Percent of immunopositive area (\% Field Area) (immunopositive area/total image area $\times 100$ ) was determined for all the markers studied by averaging images of the cortex, hippocampus and subiculum area from 2-3 sections per animal. Digital images were obtained using the same settings and the segmentation parameters constant within a range per given marker and experiment. The mean value of the\% Field Area for each marker in each animal was averaged per genotype group with the number of animals per group indicated in Figure legends.

\section{Enzyme-Linked Immunosorbent Assay (ELISA) for soluble and insoluble $A \beta$}

Soluble and insoluble $A \beta$ fractions were isolated from whole brain homogenates using four step extraction protocol [24]. Frozen hemibrains were sequentially extracted. At each step, sonication in an appropriate buffer was followed by centrifugation at 100,000 $\mathrm{x} g$ for $1 \mathrm{hr}$ at $4^{\circ} \mathrm{C}$. The supernatant was then removed, and the pellet was sonicated in the next solution used in the sequential extraction process. For four-step extraction, sonication of the frozen brain $(150 \mathrm{mg} / \mathrm{ml}$ wet weight) began in Tris-buffered saline (TBS) (20 mM Tris and $137 \mathrm{mM} \mathrm{NaCl}, \mathrm{pH}$ 7.6), which contained protease inhibitors (Protease inhibitor cocktail from Sigma St. Louis USA). The next three sequential extraction steps used $1 \%$ Triton X-100 in TBS with protease inhibitors, $2 \%$ SDS in water with the same protease inhibitors, and $70 \%$ formic acid (FA) in water. Soluble fractions were loaded directly onto ELISA plates, whereas insoluble fractions were diluted 1:20 in a neutralization buffer $(1 \mathrm{~mol} / \mathrm{L}$ Tris base, $0.5 \mathrm{~mol} / \mathrm{L} \mathrm{NaH} 2 \mathrm{PO} 4)$ before loading. MaxiSorp immunoplates (Nunc, Rochester, NY) were coated with Mab 20.1 antibody (a kind gift from Dr. David Cribbs University of California Irvine) at a concentration of $25 \mu \mathrm{g} / \mathrm{ml}$ in coating buffer $(0.1 \mathrm{M} / \mathrm{L} \mathrm{Na} 2 \mathrm{CO} 3, \mathrm{pH} 9.6)$ and blocked with $3 \%$ bovine serum albumin. Standard solutions for both $A \beta 40$ and $A \beta 42$ were made in the antigen capture buffer (20 mmol/L NaH2PO4, $2 \mathrm{mmol} /$ EDTA, 0.4 M NaCl, 0.05\% 3-[(3- cholamidopropyl) dimethylammonio] propanesulfonate, and $1 \%$ bovine serum albumin, $\mathrm{pH}$ 7.0) and loaded onto ELISA plates in duplicate. Samples were then loaded (also in duplicate) and incubated overnight at $4^{\circ} \mathrm{C}$. Plates were then washed and probed with either horseradish peroxidase conjugated anti-A $\beta 40(C 49)$ or anti-A $\beta 42(D 32)$ overnight at $4{ }^{\circ} \mathrm{C}$. The chromogen was $3,3,5,5$ tetramethylbenzidine, and the reaction was stopped by $30 \%$ phosphoric acid. The plates were read at $450 \mathrm{~nm}$ using a plate reader (Molecular Dynamics, Sunnyvale, CA). The readings were then normalized to protein concentrations of the samples.

\section{Micro hemorrhage analysis}

Coronal brain sections were stained for hemosiderin as previously described [18]. 3 different sections were counted for each mouse and scored independently by two investigators as stage $1-4$. Stage 1 is defined as " 1 to 5 grains of iron or small micro vessel involvement"; stage 2 is "multiple grains of iron and micro vessel involvement"; Stage 3 is "several positive micro vessels in 1 area"; and Stage 4 is "large blood vessel involvement". The data shown are the averages of the two independent countings and are presented as the mean $+/$ - the standard error of the mean.

\section{Statistical analysis}

All statistical analysis were performed using GraphPad Prism 5 (GraphPad Software, San Diego, CA). For comparison between antigen vaccinated groups and control vaccinated group, one-way analysis of variance (ANOVA) followed by Dunnet post-test was performed. Probability values less than 0.05 were accepted as statistically significant.

\section{Competing interests}

The authors declare no competing interests.

\section{Authors' contributions}

SR prepared the antigens, immunized the Tg2576 mice and did the biochemical and immunological characterization. HM-C and AT did the cognitive function tests. LB and AP did the sera titration. JW did the activated astrocyte quantification. SM synthesized the peptides. RA performed the ELISA. SUM and RA conducted the micro hemorrhage analysis. RK characterized the $3 \mathrm{~A}$ oligomer mimics immunoreactivity. FLaF analyzed the behavioral data. CG participated in concept, design, data analysis and manuscript preparation. All authors read and approved the final manuscript.

\section{Acknowledgements}

The authors thank Dr. Vitaly Vasilevko for helpful discussion about micro hemorrhage. Supported by NIH AG33069, a UC Biostar Discovery grant and the Larry L. Hillblom Foundation.

\section{Author details}

'Department of Molecular Biology and Biochemistry, University of California, Irvine, CA 92697, USA. ${ }^{2}$ Current affiliation: Department of Physiology and Neurosciences New York University School of Medicine New York, New York, NY 10016, USA. ${ }^{3}$ Department of Neurology and Institute of Memory Impairment and Neurological disorders, University of California, Irvine, CA 92697, USA. ${ }^{4}$ The George P. and Cynthia Woods Mitchell Center for Neurodegenerative Diseases, Department of Neurology, University of Texas Medical Branch, Galveston, TX 77555-1045, USA. ${ }^{5}$ Departments of Neuroscience and Cell Biology, The University of Texas Medical Branch, Galveston, TX 77555-1045, USA.

Received: 29 September 2011 Accepted: 17 July 2012

Published: 6 August 2012

\section{References}

1. Braak H, Braak E: Neuropathological stageing of Alzheimer-related changes. Acta Neuropathol (Berl) 1991, 82(4):239-259. 
2. Hardy JA, Higgins GA: Alzheimer's disease: the amyloid cascade hypothesis. Science 1992, 256(5054):184-185.

3. Selkoe DJ: Amyloid beta-protein and the genetics of Alzheimer's disease. J Biol Chem 1996, 271(31):18295-18298.

4. Golde TE, Dickson D, Hutton M: Filling the gaps in the abeta cascade hypothesis of Alzheimer's disease. Curr Alzheimer Res 2006, 3(5):421-430.

5. Lesne S, Koh MT, Kotilinek L, Kayed R, Glabe CG, Yang A, et al: A specific amyloid-beta protein assembly in the brain impairs memory. Nature 2006, 440(7082):352-357.

6. Mucke L, Masliah E, Yu GQ, Mallory M, Rockenstein EM, Tatsuno G, et al: High-level neuronal expression of abeta 1-42 in wild-type human amyloid protein precursor transgenic mice: synaptotoxicity without plaque formation. J Neurosci 2000, 20(11):4050-4058.

7. Walsh DM, Klyubin I, Fadeeva JV, Cullen WK, Anwyl R, Wolfe MS, et al: Naturally secreted oligomers of amyloid beta protein potently inhibit hippocampal long-term potentiation in vivo. Nature 2002, 416(6880):535-539.

8. Lue LF, Kuo YM, Roher AE, Brachova L, Shen Y, Sue $L$, et al: Soluble amyloid beta peptide concentration as a predictor of synaptic change in Alzheimer's disease. Am J Pathol 1999, 155(3):853-862.

9. Walsh DM, Klyubin I, Fadeeva JV, Rowan MJ, Selkoe DJ: Amyloid-beta oligomers: their production, toxicity and therapeutic inhibition. Biochem Soc Trans 2002, 30(4):552-557.

10. Schenk D, Barbour R, Dunn W, Gordon G, Grajeda H, Guido T, et al: Immunization with amyloid-beta attenuates Alzheimer-disease-like pathology in the PDAPP mouse [see comments]. Nature 1999, 400(6740):173-177.

11. Wisniewski T, Konietzko U: Amyloid-beta immunisation for Alzheimer's disease. Lancet Neurol 2008, 7(9):805-811.

12. Zhou J, Fonseca MI, Kayed R, Webster SD, Hernandez I, Yazan O, et al: Novel Abeta peptide immunogens modulate plaque pathology and inflammation in a murine model of Alzheimer's Disease. J Neuroinflammation 2005, 2(1):28.

13. Kayed R, Head E, Sarsoza F, Saing T, Cotman CW, Necula M, et al: Fibril specific, conformation dependent antibodies recognize a generic epitope common to amyloid fibrils and fibrillar oligomers that is absent in prefibrillar oligomers. Mol Neurodegener 2007, 2(18):18.

14. Goni F, Prelli F, Ji Y, Scholtzova H, Yang J, Sun Y, et al: Immunomodulation targeting abnormal protein conformation reduces pathology in a mouse model of Alzheimer's disease. PLoS One 2010, 5(10):e13391.

15. Aloisi F: Immune function of microglia. Glia 2001, 36(2):165-179.

16. Streit WJ: Microglia and Alzheimer's disease pathogenesis. J Neurosci Res 2004, 77(1):1-8.

17. Wilcock DM, Colton CA: Immunotherapy, vascular pathology, and microhemorrhages in transgenic mice. CNS Neurol Disord Drug Targets 2009, 8:50-64.

18. Fisher M, Vasilevko V, Passos GF, Ventura C, Quiring D, Cribbs DH: Therapeutic modulation of cerebral microhemorrhage in a mouse model of cerebral amyloid angiopathy. Stroke 2011, 42:3300-3303.

19. Hardy J, Selkoe DJ: The amyloid hypothesis of Alzheimer's disease: progress and problems on the road to therapeutics. Science 2002, 297(5580):353-356.

20. Schenk D: Opinion: Amyloid-beta immunotherapy for Alzheimer's disease: the end of the beginning. Nat Rev Neurosci 2002, 3(10):824-828.

21. Decker MW, Gill TM, McGaugh JL: Concurrent muscarinic and betaadrenergic blockade in rats impairs place-learning in a water maze and retention of inhibitory avoidance. Brain Res 1990, 513(1):81-85.

22. Gordon MN, Holcomb LA, Jantzen PT, DiCarlo G, Wilcock D, Boyett KW, et al: Time course of the development of Alzheimer-like pathology in the doubly transgenic PS1 + APP mouse. Exp Neurol 2002, 173(2):183-195.

23. Head E, Garzon-Rodriguez W, Johnson JK, Lott IT, Cotman CW, Glabe C: Oxidation of Abeta and plaque biogenesis in Alzheimer's disease and Down syndrome. Neurobiol Dis 2001, 8(5):792-806.

24. Kawarabayashi T, Younkin LH, Saido TC, Shoji M, Ashe KH, Younkin SG: Age-dependent changes in brain, CSF, and plasma amyloid (beta) protein in the Tg2576 transgenic mouse model of Alzheimer's disease. J Neurosci 2001, 21(2):372-381.

25. Su JH, Cummings BJ, Cotman CW: Plaque biogenesis in brain aging and Alzheimer's disease. II. Progressive transformation and developmental sequence of dystrophic neurites. Acta Neuropathol 1998, 96(5):463-471

26. Bard F, Cannon C, Barbour R, Burke RL, Games D, Grajeda H, et al: Peripherally administered antibodies against amyloid beta-peptide enter the central nervous system and reduce pathology in a mouse model of Alzheimer disease. Nat Med 2000, 6(8):916-919.

27. Bacskai BJ, Kajdasz ST, McLellan ME, Games D, Seubert P, Schenk D, et al: Non-Fc-mediated mechanisms are involved in clearance of amyloid-beta in vivo by immunotherapy. J Neurosci 2002, 22(18):7873-7878.

28. Morgan D, Diamond DM, Gottschall PE, Ugen KE, Dickey C, Hardy J, et al: A beta peptide vaccination prevents memory loss in an animal model of Alzheimer's disease. Nature 2000, 408(6815):982-985.

29. Janus C, Pearson J, McLaurin J, Mathews PM, Jiang Y, Schmidt SD, et al: A beta peptide immunization reduces behavioural impairment and plaques in a model of Alzheimer's disease. [Comment In: Nature. 2000 Dec 21-28;408(6815):915-6 UI: 21020929]. Nature 2000, 408(6815):979-982.

30. Kotilinek LA, Bacskai B, Westerman M, Kawarabayashi T, Younkin L, Hyman BT, et al: Reversible memory loss in a mouse transgenic model of Alzheimer's disease. J Neurosci 2002, 22(15):6331-6335.

31. Orgogozo JM, Gilman S, Dartigues JF, Laurent B, Puel M, Kirby LC, et al: Subacute meningoencephalitis in a subset of patients with $A D$ after Abeta42 immunization. Neurology 2003, 61(1):46-54.

32. Masliah E, Hansen L, Adame A, Crews L, Bard F, Lee C, et al: Abeta vaccination effects on plaque pathology in the absence of encephalitis in Alzheimer disease. Neurology 2005, 64(1):129-131.

33. Nicoll JA, Wilkinson D, Holmes C, Steart P, Markham H, Weller RO: Neuropathology of human Alzheimer disease after immunization with amyloid-beta peptide: a case report. Nat Med 2003, 9(4):448-452.

34. Ferrer I, Boada Rovira M, Sanchez Guerra ML, Rey MJ, Costa-Jussa F: Neuropathology and pathogenesis of encephalitis following amyloid-beta immunization in Alzheimer's disease. Brain Pathol 2004, 14(1):11-20.

35. Gilman S, Koller M, Black RS, Jenkins L, Griffith SG, Fox NC, et al: Clinical effects of Abeta immunization (AN1792) in patients with AD in an interrupted trial. Neurology 2005, 64(9):1553-1562.

36. Patton RL, Kalback WM, Esh CL, Kokjohn TA, Van Vickle GD, Luehrs DC, et al: Amyloid-beta peptide remnants in AN-1792-immunized Alzheimer's disease patients: a biochemical analysis. Am J Pathol 2006, 169(3):1048-1063.

37. Nicoll JA, Barton E, Boche D, Neal JW, Ferrer I, Thompson P, et al: Abeta species removal after abeta42 immunization. J Neuropathol Exp Neurol 2006, 65(11):1040-1048.

38. Britschgi M, Olin CE, Johns HT, Takeda-Uchimura Y, LeMieux MC, Rufibach $K$, et al: Neuroprotective natural antibodies to assemblies of amyloidogenic peptides decrease with normal aging and advancing Alzheimer's disease. Proc Natl Acad Sci U S A 2009, 106(29):12145-12150.

39. Fillit $H$, Hess $G$, Hill J, Bonnet $P$, Toso C: IV immunoglobulin is associated with a reduced risk of Alzheimer disease and related disorders. Neurology 2009, 73(3):180-185.

40. Kayed R, Head E, Thompson JL, McIntire TM, Milton SC, Cotman CW, et al: Common structure of soluble amyloid oligomers implies common mechanism of pathogenesis. Science 2003, 300(5618):486-489.

41. Petkova AT, Leapman RD, Guo Z, Yau WM, Mattson MP, Tycko R: Self-propagating, molecular-level polymorphism in Alzheimer's beta-amyloid fibrils. Science 2005, 307(5707):262-265.

42. Kodali $R$, Williams AD, Chemuru S, Wetzel R: Abeta(1-40) forms five distinct amyloid structures whose beta-sheet contents and fibril stabilities are correlated. J Mol Biol 2010, 401(3):503-517.

43. Glabe CG: Structural classification of toxic amyloid oligomers. J Bio/ Chem 2008, 283(44):29639-29643.

44. Necula M, Kayed R, Milton S, Glabe CG: Small molecule inhibitors of aggregation indicate that amyloid beta oligomerization and fibrillization pathways are independent and distinct. J Biol Chem 2007 282(14):10311-10324

45. Kayed R, Canto I, Breydo L, Rasool S, Lukacsovich T, Wu J, et al: Conformation dependent monoclonal antibodies distinguish different replicating strains or conformers of prefibrillar Abeta oligomers. $\mathrm{Mol}$ Neurodegener, 5:57 
46. Kayed R, Glabe CG: Conformation-dependent anti-amyloid oligomer antibodies. Methods Enzymol 2006, 413:326-344.

47. Billings $L M$, Oddo S, Green KN, McGaugh JL, Laferla FM: Intraneuronal Abeta causes the onset of early Alzheimer's disease-related cognitive deficits in transgenic mice. Neuron 2005, 45(5):675-688.

48. Chen G, Chen KS, Knox J, Inglis J, Bernard A, Martin SJ, et al: A learning deficit related to age and beta-amyloid plaques in a mouse model of Alzheimer's disease. Nature 2000, 408(6815):975-979.

49. Dodart JC, Bales KR, Gannon KS, Greene SJ, DeMattos RB, Mathis C, et al: Immunization reverses memory deficits without reducing brain Abeta burden in Alzheimer's disease model. Nat Neurosci 2002, 5(5):452-457.

doi:10.1186/1750-1326-7-37

Cite this article as: Rasool et al:: Vaccination with a non-human random sequence amyloid oligomer mimic results in improved cognitive function and reduced plaque deposition and micro hemorrhage in Tg2576 mice. Molecular Neurodegeneration 2012 7:37.

\section{Submit your next manuscript to BioMed Central and take full advantage of:}

- Convenient online submission

- Thorough peer review

- No space constraints or color figure charges

- Immediate publication on acceptance

- Inclusion in PubMed, CAS, Scopus and Google Scholar

- Research which is freely available for redistribution 